\title{
An Evaluation of Sindh Schools Education System: Problems and Possibilities
}

\author{
Mr. Zamir Ahmed Khoso \\ Regional Director \\ College Education Department Government of Sindh Karachi, Pakistan.
}

Mr. Mazhar Ali Siddiqui

Director General Planning Development \& Research, School Education \& Literacy Department Government of Sindh Karachi, Pakistan.

\author{
Mr. Ali Akbar Tagar \\ Section Officer (Development)
}

School Education \& Literacy Department Government of Sindh Karachi, Pakistan.

Dr. Hamzo Khan Tagar

Director Public Private Partnership Node,

School Education \& Literacy Department, Government of Sindh, Karachi Pakistan.

\begin{abstract}
This paper has been written in the context of quality education in Sindh province of Pakistan. The system has been examined through descriptive manner and in a broad context to sort out the major problems of the system, and also to provide feasible policy recommendations to improve the system in the greater public interest. Because literacy is a weapon of the 21st century to fight with poverty, illiteracy, hunger, socioeconomic evils and with global terrorism to secure and safeguard the rights of future generations. Through this paper, the Government of Sindh has been updated about grey areas in their education system, feasible solutions which includes, merit and needbased recruitment of teachers, pre-service teachers trainings, condition of teachers license, posting of competent teacher as " head teacher", appointment of professional officers against managerial positions, curriculum and textbook development, reopening of feasible closed schools through intervention of public-private partnership node and Sindh Education Foundation, development of education policy based on Standardized Achievement Test ( SAT) and Provincial Education Assessment Center (PEACE) results / reports and establishment of one model primary (Male \& Female) and Secondary School in each tehsil of the district with all required facilities, including adequate budget to create competitive atmosphere amongst public and private sector schools. The implementation of formal and non-formal education and revitalization of vocational and technical institutions have also been recommended to create employment for youths.
\end{abstract}

Keywords: School Education System, Literacy, Challenges, Opportunities, Problems

\section{Importance of Education}

\section{INTRODUCTION}

Education in common usage that education is merely the delivery of knowledge, skills and information from teacher to student is inadequate to capture what is really important about me in. It is also defined as the process of becoming an educated person. Being an educated person means you have access to optimal states of mind regardless of the situation you are in. No country can progress without having a sound education system. Those developing nations who realize this earlier; works effectively for sustainable development of economy and society. 
The most important resource of a nation is its human capital. Cultured and wise men are the product of an effective education system. The ethical, moral, and educational facilities given to the children of today can help them in becoming a responsible citizen of tomorrow. New ideas, concepts, effective and innovative ways to do things comes only when the education system is strong and benefiting the brilliant minds. Sindh province being economically established plays an important role in term of country's economy with a large population, but unfortunately the standard of education is by far lowest, however, despite certain improvement in some sectors particularly in urban areas, the overall education has a provoking condition in Sindh. The reports released by various local and international organizations, including the World Bank (W.B) and United Nations International Children's Emergency Fund (UNICEF) reflects low progress in Sindh education sector. The commitment made by Sindh Government with different organizations is also lagging behind in many fields / areas despite appropriate flow of funds and even promulgation of Constitutional Legislations-Article 25-A which says "the State shall provide free and compulsory education to all children of the age of five to sixteen years in such a manner as may be determined by law". [1].

The below discussed time-barred education system of the province and lack of coherent planning above referred constitutional obligations cannot flame the candelas of literacy in the province. This Paper has been written in the above context to evaluate the school education system of Sindh province in details and suggests recommendation for improvement in schools in public interest.

\section{Objectives of the Study:}

The specific objectives of the study were to:

i. An evaluation of Sindh Education system and its performance in literacy.

ii. Assess how management has organized its educational activities in context of literacy trends in the province.

iii. Examine major obstacles in implementation of Article 25-A of the constitutions

\section{Research Questions}

The study was guided by the following questions:

I. what were the major obstacles in implementation of constitutional obligation of Article $25 \mathrm{~A}$

II. How have Provincial Management acted against illiteracy and gender disparities?

III. What is the result of in terms of literacy rate $\%$ to bring universal primary education in the province?

\section{Significance of the Study}

The study sorted out major obstacles in the school education system and findings of the study can be used by the policymakers to improve the system required for quality education as driven demand.

\section{METHODOLOGY\& DATA}

The authors are serving in education and literacy department for the last 3 decades so their personal observations as an education expert, an outcome of specific and targets groups, primary and secondary data of some individuals and organizations have been used to strengthen the hypothesis. The qualitative /descriptive statistics strategy has been adopted to identify the issues in Sindh School's system in public interest and in systemically order and also provides a recommendation for further improvements for the greater cause of quality education for all. 


\section{DISCUSSION AND RESULT}

The Education System and Enrollment in Sindh Region: It is generally divided into six levels; a preschool system is introduced recently as early childhood education and development system for the kids' age from 3 to 5 years in the province. The primary education system is older since long from grades one through five it is the backbone the whole education system in the region. Middle schooling is based on through six through eight. High (grades nine and ten, leading to the Secondary School Certificate or SSC), intermediate (grades eleven and twelve, leading to a Higher Secondary School Certificate and university programs leading to undergraduate and graduate degrees.

This further divided as boys and girls and mixed or co-education in which girls and boys are studying together as mentioned in column number four in table 01 . The table 01 below is selfexplanatory and shown total numbers of schools are 45445, total numbers of enrollment are 4145,219 , enrolment of girls are very tinny as 1626,039 , the numbers of teachers are156,216. The male teachers are double than female and female teachers' numbers are 50,097 in comparison of male as 106,119 as in details given below.

Table-01: Number of Institutes, Enrolment and Teachers in Sindh Province

\begin{tabular}{|c|c|c|c|c|c|c|c|c|c|c|}
\hline \multirow{2}{*}{$\begin{array}{l}\text { Sindh } \\
\text { Province } \\
\text { School Level }\end{array}$} & \multicolumn{4}{|c|}{ Number of Institutes } & \multicolumn{3}{|c|}{ Enrolment } & \multicolumn{3}{|c|}{ Teacher } \\
\hline & Boys & Girls & Co-Ed & Total & Boys & Girls & Total & Male & Female & Total \\
\hline Primary & 9,271 & 5,711 & 26,149 & 41,131 & $1,648,607$ & $1,039,794$ & $2,688,401$ & 68,428 & 24,514 & 92,942 \\
\hline $\begin{array}{l}\text { Middle/ } \\
\text { Elementary }\end{array}$ & 513 & 593 & 1,223 & 2,329 & 147,898 & 117,948 & 265,846 & 8,395 & 5,215 & 13,610 \\
\hline Secondary & 564 & 488 & 644 & 1,696 & 490,291 & 346,103 & 836,394 & 22,207 & 16,604 & 38,811 \\
\hline $\begin{array}{l}\text { Higher } \\
\text { Secondary }\end{array}$ & 87 & 76 & 128 & 291 & 232,384 & 122,194 & 354,578 & 7,089 & 3,764 & 10,853 \\
\hline Total: & 10,345 & 6,808 & 28,144 & 45,447 & $2,519,180$ & $1,626,039$ & $4,145,219$ & 106,119 & 50,097 & 156,216 \\
\hline
\end{tabular}

[2] SEMIS Census 2015 - 2016

It is a fact that despite many reforms and efforts in the last one decade with help of world bank European union UNICEF union global partnership in education sector by the reputed dangers organization's and non-governmental partners, Sindh has not performed well to reduce the out-of-school children ratio, including both the drop-outs and left-outs, which nearly remains the same over the last few years. It is estimated that there are 12 million children of age 5-16 years in the province, out of which 6.67 million (approx. 56\%) are out of school. However, the recent data shows a decline in drop-outs from $23.9 \%$ in the year $2012-2013$ to $20 \%$ in the year 2013-14, and a further decline to 13\% in the year 2014-15. Sindh has the second highest number of out-of-school children in Pakistan, after Baluchistan. Khyber Pakhtunkhwa has been able to reduce the number of out-of-school children in recent years, and currently, it has the lowest percentage (approx. 36\%) of out-of-school children. [3]

Quality Education: Another challenge being faced by Sindh is the quality of the education. The findings of the National Education Assessment System (NEAS), Provincial Education Assessment System, Standard Achievement Test, and others confirm apprehensions that public education is on the verge of collapse. A study conducted by the Annual School Examination Report (ASER) focusing on student competencies in learning English, Arithmetic, and Language have dipped compared to 2015. "63 percent of the children from Class V cannot read Class II level story text in Urdu and Sindhi. In English, only 19 percent of the surveyed Class V students could read sentences, which should ideally read by students from the second grade. Arithmetic learning levels also have gone down where only 24 percent of Class V children could do a twodigit division, something that is expected in the second-grade curriculum".[4] 
Education Emergency: Having received alarming news of ever deteriorating standard of education in the province, the government announced an emergency in Sindh in the education sector to overhaul it. There were numbers of grey area which were pointed out by policy managers and announced different strategies to overcome it. However, efforts made in this regard are of a traditional type, therefore; there seems no progress as earmarked. Even the four thousand primary schools identified by the department as model schools, to be equipped with all facilities, to implement directives of government Sindh, have not been upgraded so far. Regarding formation of committee to overcome the existing deteriorating education sector it is said that establishing an institution to run another institution and recruiting monitoring bodies, and constitution of committee after committee for the purpose of overseeing or suggesting, improving mechanism is adhocism which has not yielded desired results nor will it be fruitful in foreseeable future because such an exercise is based on idealism/day-dreaming.

Biometrics System: Sindh education department has introduced the biometric system in Sindh to take biometric attendance of the staff in schools. No doubt, biometric system has brought little progress in the educational sector as it has ensured the attendance of staff to some extent. But it has created problems for punctual and regular teachers as well. A considerable number of teachers have taken volunteer retirement due to the unfriendly monitoring system and stoppage of their salaries since years.

Examinations: Examination system in Sindh also is fraught with faults because it tests memory power rather than intelligence and intellectual approach of the students. The education system in Sindh puts more emphasis on the theoretical knowledge than the practical. A student from the very beginning of education is forced to copy up the things rather than to understand the thoughts. Examination system, unfortunately, provides rote learning than understandings.

Service Delivery: The Government of Sindh has introduced number of reforms that are significant in addressing various gaps in education service delivery. However, the speed of these reforms is slow which needs to be speed up to address the plethora of problems that ail the province's education system.

Governance: The review reports of different organizations of local and international repute reveal that almost all initiatives taken by Sindh Education Department such as Sindh Education Sector Plan-I\&II, Sindh Education Sector Plan (2014-2018), Sindh Education Foundation (SEF), Sindh Education Policy, Curriculum and Textbook Development, achievements of Millennium Development Goals (MDGs), implementation of school achievements and assessments reports and Article 25-A are lagging behind despite using adequate budget released against each program. Even there seems no implementation strategy prepared while announcing a state of emergency in the education sector. This lagging is because of many reasons but the core one is posting of corrupt, inexperienced, incompetent, unprofessional and politically motivated officers against managerial positions. The posting of almost all staff of Directorate of private schools for ten plus years at the same place without any transfer is one of the worst examples to be quoted to examine the performance of Sindh Education sector.

Infrastructure: The overall academic standard of education and literacy in Sindh is deplorable because of poor infrastructure and necessary missing facilities which includes drinking water, toilet, and boundary walls. Above situation insist us to develop sustainable policy overcome the infrastructural dilemma in Sindh schools because of literacy and infrastructural nexus in long run planning of quality education for all. 
Devolution of Powers: Currently, the education system in Sindh has been facing enormous problems which include: low literacy rate, high drop-out ratio, lack of quality education, a large number of closed schools, lack of basic facilities in schools-drinking water, toilets, classrooms and boundary walls etc.-and lack of girl's schools in a large number of remote villages. There is a need to evolve a policy of decentralization of powers encouraging effective monitoring and implementation systems. Monitoring officials at Union Council (UC) level are influenced by the local politicians to manage human and financial resources of schools in their jurisdiction. They are less empowered to proposed need-based transfers and postings of teachers. When these grass-root officials are made fully capable of making decisions, then it necessitates that they should be held responsible to ensure the required enrollment of children and provision of quality education. They may be made accountable for all the issues faced by schools in their domain. An effective monitoring system should be put to watch the activities of devolved offices particularly in connection with transfer and postings.

Curriculum Development: It is said that the curriculum is the backbone of the education system. The Sindh Education Department after 18th constitutional amendment established certain committees to develop new Sindh based curriculum and preparation of new textbooks accordingly, but the outcome is awaited until. The teachers in Sindh used textbooks to teach their students developed based on outdated / three-decade-old curriculum. Therefore, there is a need to develop a workable curriculum with the help of leading and liberal-minded educationists, literary figures and scholars that can meet the requirements of modern needs. The quality of education really depends upon the contents of the curriculum and the development of a scheme for studies.

Scarcity of Resources: It is an internationally accepted policy that the government administering education must spend 4\% of Gross Development Product (GDP) on education. The Sindh government roughly spends 21 to 23 percent of its budget on education. Low flow of funds has badly affected implementation of Education commitments of Sindh Government made at various forums including implementation of Sindh Education Sector Plan (20142018), and Article 25-A.

Teacher's Recruitment and Trainings: For the smooth functioning of any organization, human resources play one of the significant roles, and in case of their shortage, the organization does not function properly. According to Sindh Education Department's estimates, around 3,000 posts of teachers fall vacant every year due to the retirement of teachers creating a gap to be filled immediately for sustainability of academic activities/process, but regrettably, recruitments of teachers are made after a long gap of two to three years. Meanwhile, the Education Department suffers a shortage of teachers, which affects the academic process. This situation requires the introduction of the rational teacher recruitment policy in order to harvest the constructive results of the envisioned schemes. Sindh Government's merit and need-based recruitment of teachers made through testing by different testing agencies in the years in last one decade has been much appreciated by almost all stakeholders including the parents. The assessment study conducted in connection with the performance of these teachers reveals that these teachers are performing well in comparison to those recruited earlier in a very traditional manner. Continuous Professional development of teachers is a pre-requisite for providing quality education to the children and it has a positive impact on learning achievement of the students. Whether in schools, colleges or universities, teachers, who work as catalysts of change, play an essential role in promoting quality education. No matter what initiatives and measures are taken, no education reform is likely to succeed without the active participation and ownership of professionally trained teachers. 
Infective Role of Policy Planners and Gender Gap in Enrollment: Sindh is southern province of the Country with vast resources potential but it's in grip of vicious circle of poverty, illiteracy and energy crisis, which is product of inequality, corruption and large-scale mismanagement of its elite class because they are not real stakeholders of the public sector education and completely depends on private sector schools situated in posh area of urban centers or an abroad. Female literacy which is a backbone of developed economies and civilized societies are not progressive as invested, overall $44 \%$ which is mostly in urban centers in rural Sind female literacy is less than $19 \%$ as recent data of an economic survey of Pakistan 2017-18 details are given below in the last columnoftable02.

Decreasing over all Literacy Trends: The public sector schools are producing time-barred incompetent and unskilled youth in the global age of 21st century. In these yellow schools of government only child of urban labor/village farmers and lower middle class are enrolled in a vast majority but overall literacy trends are not satisfactory and progressive but decreasing as mentioned in table 02-year wise comparison. It is very alarming that overall literacy trends are decreasing but the proportion salary and development funds are on an increasing path. The total expenditure including salary and development is increasing sharply from $76 \%$ to $91 \%$ and development expenditure from 36\% to 58\% except for the year of 2011 as shown in table 03. The lowest utilization of 2011 was shifting of resources to support the affecters of supper flood of 2010 which loses hundreds of billions to the province and national exchequer also.

Table -02 Sindh Adult Literacy Rate Above 10 Years

\begin{tabular}{|l|c|c|c|c|c|c|c|}
\hline Year & $\begin{array}{c}\text { Total Literacy } \\
\text { Rate in Sindh }\end{array}$ & Male & FEMALE & Urban Male & $\begin{array}{c}\text { Urban } \\
\text { Female }\end{array}$ & $\begin{array}{c}\text { Rural } \\
\text { Male }\end{array}$ & $\begin{array}{c}\text { Rural } \\
\text { Female }\end{array}$ \\
\hline $\mathbf{2 0 1 3 - 1 4}$ & 56 & 67 & 43 & 80 & 63 & 53 & 21 \\
\hline & & & & & & & \\
\hline $\mathbf{2 0 1 5 - 1 6}$ & 55 & 67 & 44 & 80 & 65 & 51 & 19 \\
\hline & & & & & & & \\
\hline
\end{tabular}

[1] Pakistan Government of (2016), Economic Survey of Pakistan. Islamabad, Ministry of Finance \& Economic Affairs Division. pp 156.

Table -03 Province Wise Salary Expenditure of Education Sector

\begin{tabular}{|l|c|c|c|c|c|}
\hline $\begin{array}{l}\text { Sindh Education } \\
\text { Expenditure }\end{array}$ & FY2010 & FY2011 & FY2012 & FY2013 & FY2014 \\
\hline Salary & $76 \%$ & $131 \%$ & $103 \%$ & $92 \%$ & $91 \%$ \\
\hline Development & $36 \%$ & 06 & $41 \%$ & $33 \%$ & $58 \%$ \\
\hline & & & & & \\
\hline
\end{tabular}

[5] Nadia Naveen 2016 "Pakistan's Education Crisis: The Real Story"

As there seems increased in public sector funding for educational development as mentioned in table 03 above, but year wise increase and decrease in budget particularly against development component shows an unjustified flow of funds without determining any feasibility against the program. This is an incremental approach and indicates mismanagement at large in public sector development programs. This also shows the failure of program managers, monitoring or supervisory bodies, and planners, therefore, they must be made accountable for it.

\section{RECOMMENDATIONS}

Inside schools, there are challenges which include a shortage of teachers, teacher-student ratio, absenteeism, missing basic facilities and lack of friendly environment. However, out of school challenges include shortage of schools, distance - especially for females, insecurity, poverty, cultural norms and lack of awareness of parents. There is dire need to recruit merit and need- 
based teachers to ensure quality education in schools. The assessment study made by an independent party to gauge the performance of teachers appointed through IBA, Sukkur, University of Sindh, Jamshoro and National Testing Service (NTS) shows these teachers are performing well in comparison to those appointed in a very traditional manner. There is a need to develop permanent recruitment of teacher's policy to ensure timely recruitment of teachers against each vacant position. he targets of achieving quality education could only be met if teachers are competent, trained and dedicated. The availability of teacher in each school matters. The curriculum plays a vital role to create uniformity in the behavior of different communities and is a source of national integrity hence its development matters. The development of new curriculum and textbooks accordingly, will be productive towards quality education. The budget allocated against the development of schools is usually lapsed at the end of the financial year because of delay in release or non-utilization. This inconsistency in the system needs to be addressed with workable accountability mechanism. An appropriate budget is required to be released to ensure implementation of Article 25-A, Education for All commitments, Sindh Education Sector Plan and directives of policymakers and implementing authorities regarding up gradation of four thousand primary schools as a model in phase-I

The majority of the population resides in rural areas and the access to education is a major problem for them, therefore, adoption of formal and informal education would be productive. The Sindh government should pay attention to vocational and technical training centers create skilled youth, particularly in rural area. Secondary education classes for carpentry, electrical, and other technical education must be included in the curriculum. An effective district wise monitoring system is required to be developed to conduct inspections of schools on regular basis and provides feedback if necessary. The official data shows enormous allocation of funds for educational projects both from government and donors' side, but contrary the outcome is very low. The reason is no placement of an effective monitoring and budget tracking system with timeline. The existing infrastructure is not as per requirements of the students which discourage students' enrollment and promotes absenteeism and drop out. Special policy planning units should be established in education departments for the implementation of educational policies and the formulation of new policies whenever needed.

The local government system is helpful in promoting education and literacy in the province. In local government, there is developed a system to track the flow of funds and do effective monitoring at a grass root level. Corruption in education departments is one of the factors for poor literacy in the province. An effective monitoring system is needed to be put in place as the biometric system only ensures the presence of staff. Unemployment of educated men and women is a major concern for the province. There should be career counseling of the pupils in schools so that they understand the job market and they can develop their skills accordingly. Counseling of parents is also required so that they can choose a career for their child which is market-friendly. Focus on teacher's attendance and their capacity building with revised curriculums per global standard with improvement in infrastructure will be a game changer. Special incentives for girls and out of school children will also be a feasible option for improvements at large. The reforms required in the education system of Sindh cannot be done by the government alone, public-private participation and a mix of formal as well as nonformal education can pull out a majority of province population from illiteracy. Similarly, to make the youth of the province an asset, attention should also be paid to vocational and technical training. The hiring of teachers should be linked with merit, teachers' license, and training to ensure quality education. The identification and launch of one male and female primary and secondary school at union council and Taluka level, a model school, with all required facilities, would be productive to attract local population, enhance enrollment 
towards public sector schools. Early child education initiatives are also needed of the hour in long term development strategy in the province.

The study made in the context reveals that the low standard of education in Sindh is because of many reasons in the present system which includes a shortage of subject teachers, proportional gap in teachers retirement and recruitment, induction of untrained teachers, ineffective students learning process, stagnant textbooks developed three decades earlier, low budget for schools infrastructure, duplication of programs, inconsistent data of schools, less focus on non-formal education and revitalization of vocational / technical training institutions. Above mentioned issues direly need to adopt an innovative approach to tackle all obstacle's in decent manners and through improving the whole system by proper policies and practices in the field.

\section{CONCLUSION}

The study made in the context reveals that the low standard of education in Sindh is because of many reasons in the present system which includes a shortage of subject teachers, proportional gap in teachers retirement and recruitment, induction of untrained teachers, ineffective students learning process, stagnant textbooks developed three decades earlier, low budget for schools infrastructure, duplication of programs, inconsistent data of schools, less focus on non-formal education and revitalization of vocational / technical training institutions. Above mentioned issues direly need to adopt an innovative approach to tackle all obstacle's in decent manners and through improving the whole system by proper policies and practices in the field.

\section{References}

Pakistan Government of (2014-15), Economic Survey of Pakistan. Islamabad, Ministry of Finance \& Economic Affairs Division. pp 156.

Sindh Education Management Information System (SEMIS) Yearly Report 2015-16.

Pakistan Education Statistics 2015-16. pp.37-40.

Annual School Examination Report (ASER) 2016-17, Islamabad Pakistan.pp192-110

Nadia Naveen 2016 "Pakistan's Education Crisis: The Real Story” Woodrow Wilson International Center for Scholars One Woodrow Wilson Plaza 1300 Pennsylvania Avenue NW Washington, D.C. 20004-

3027.www.wilsoncenter.org. pp 8. 